\title{
ВИКОРИСТАННЯ АВТОМОБІЛЬНОГО ТРАНСПОРТУ В СІЛЬСЬКОГОСПОДАРСЬКОМУ ВИРОБНИЦТВІ
}

\begin{abstract}
Розвиток сільськогосподарського виробництва безпосередньо залежить від стану технологічної бази сільськогосподарських товаровиробників. Автомобільний транспорт знайшов значне застосування при перевезенні сільськогосподарських матеріалів від місця збору врожаю до місць його зберігання та переробки. Завдання, щодо встановлення оптимального розміру автопарку є актуальним як для вантажних, так і для пасажирських перевезень. Вирішення цієї проблеми повинно забезпечити визначення складу та кількості автопарку, що забезпечило б виконання необхідних технологічних процесів, з одного боку, та максимальне виключення простоїв, що веде до додаткових витрат, 3 іншого. Автомобілі, що використовуються в сільськогосподарському виробництві, повинні відповідати відповідним експлуатаційним вимогам. До таких вимог відноситься забезпечення виконання всього комплексу сільськогосподарських робіт 3 належною продуктивністю та максимальною ефективністю. Важливими також є вимоги екологічності (викиди шкідливих компонентів і ущільнення грунту), комфорту та безпеки. Вибір оптимальної якості рухомого складу автомобільного парку нерозривно пов'язаний із встановленням оптимального терміну служби автомобіля та оцінкою його надійності. Забезпечення надійності автомобіля $є$ складною проблемою, яка починається 3 моменту його проектування, виробництва, експлуатації та належного обслуговування $\mathrm{i}$ до закінчення його експлуатації. До основних шляхів удосконалення використання рухомого складу сільськогосподарських транспортних засобів можна віднести: підвищення коефіцієнта мінливості, повноти використання у виробничих процесах, усунення простоїв, скорочення простоїв при ремонті та оглядах, стимулювання кращого використання автомобільного транспорту.

Ключові слова: автомобіль, автомобільний транспорт, сільськогосподарське виробництво, сільськогосподарські машини, рухомий склад.
\end{abstract}

\section{ВСТУП}

Сучасні технології вирощування i збирання сільськогосподарських культур володіють високими показниками механізації, іншими словами виробничі процеси виконуються за допомогою відповідних сільськогосподарських машин. У зв’язку з цим, ефективність процесів збирання врожаю у великій мірі залежить від рівня його транспортного обслуговування, яке характеризується значними обсягами перевезень у стислі терміни.

Отже, основним завданням технічної політики сільськогосподарських виробників $\epsilon$ забезпечення виконання усіх технологічних операцій iз дотриманням агротехнічних вимог $\mathrm{i}$ одночасною мінімізацією енергетичних, трудових і матеріально-технічних затрат.

3 метою вирішення даної проблеми кожен сільськогосподарський виробник має знайти «золоту середину» між обсягами робіт і рівнем їх ресурсного забезпечення.

\section{АНАЛІЗ ВІДОМИХ РЕЗУЛЬТАТІВ ДОСЛІДЖЕНЬ ТА ПОСТАНОВКА ПРОРБЛЕМИ}

Розвиток сільськогосподарського виробництва напряму залежить від стану технологічної бази сільськогосподарських виробників. Автомобільний транспорт отримав значне використання в процесах транспортування сільськогосподарських матеріалів від місця збирання врожаю до місць його зберігання та переробки. Задача встановлення оптимальної величини розміру парку рухомого складу є актуальною як для вантажних так і для пасажирських перевезень. Розв’язання даної задачі повинно забезпечити визначення складу та кількості парку автомобільного транспорту, який забезпечив би виконання необхідних технологічних процесів, з однієї сторони, та максимального усунення простоїв, що призводять до додаткових витрат, з іншої.

Особливості розвитку ринку вантажних перевезень, в тому числі і сільськогосподарських, 3 дослідженням базових чинників, які впливають на розвиток транспортних підприємств відображено в працях [1].

Формування парку автомобільного транспорту науковці розглядають як динамічне управління останнім [2], це пояснюється тим, що випадкові події (затримки, поломки і т.д.) можуть мати негативний вплив на виконання технологічних процесів. Динамічне управління рухомим складом відбувається на основі інформації, яка надходить в режимі реального часу, що в свою чергу, забезпечує підвищення ефективності використання парку автомобільного транспорту.

Автори [3] пропонують, як шлях визначення кількісного складу транспортного парку, розроблену математичну оптимізаційну модель. 
Дослідження [4] відображають спробу провести класифікацію проблем щодо формування транспортного парку, в тому числі й автомобільного. Моделі формування оптимальної структури парку рухомого складу, з врахуванням впливу випадкових подій і питомого прибутку, відображені у праці [5].

Авторами [6 - 8] проведено систематизацію критеріїв оцінки показників довговічності та надійності колісних транспортних засобів, в тому числі i тих які використовуються у сільськогосподарському виробництві, розглянуто концептуальні підходи їх пошукового конструювання з прогнозуванням ресурсу роботи.

Отже, встановлення кількісного та якісного складу автопарку сільськогосподарського підприємства $\epsilon$ актуальним завданням, розв'язання якого забезпечує підвищення ефективності діяльності сільськогосподарського, а отже конкурентоспроможності на вітчизняному та закордонних ринках.

\section{ЦІЛЬ ТА ЗАДАЧІ ДОСЛІДЖЕННЯ}

Провести аналіз рухомого складу автомобільного парку сільськогосподарських підприємств. Встановити особливості його використання. Розробити шляхи підвищення ефективності використання рухомого складу парку автомобільного транспорту в процесі сільськогосподарському виробництві.

\section{РЕЗУЛЬТАТИ ДОСЛІДЖЕННЯ}

Автомобілі - складні мобільні транспортні та енергетичні засоби, що використовуються 3 метою комплексної автоматизації та механізації сільськогосподарського виробництва, а також для транспортування пасажирів і сільськогосподарських вантажів.

Автомобілі поділяють на пасажирські (легкові, для перевезення до восьми пасажирів, автобуси - більше восьми пасажирів) та вантажні (для перевезення різного роду вантажів).

В залежності від конструктивних особливостей вантажних автомобілів, які використовуються в сільськогосподарському виробництві, їх поділяють на:

- автомобілі загального призначення;

- спеціалізовані, тобто призначені для транспортування конкретних категорій вантажів (автофургони, контейнеровози, автоцистерни, авторефрежиратори, самоскиди тощо);

- спеціальні - застосовуються, як правило, не для транспортних робіт (автокрани, пожежні, пересувні майстерні та інші).

Сільськогосподарські спеціалізовані та спеціальні автомобілі оснащенні спеціалізованим обладнанням і відповідними пристроями, як правило це видозмінені моделі транспортних засобів 3 обмеженим колом використання.

Автомобілі, які використовуються у сільськогосподарському виробництві, повинні задовольняти відповідні експлуатаційні вимоги. До таких вимог належать забезпечення виконання всього комплексу сільськогосподарських робіт 3 належною продуктивністю та максимальною економічністю. Важливе значення займають також вимоги щодо екологічності (викиди в атмосферу шкідливих компонентів і ущільнення грунтів) та комфортності й безпечності праці.

Продуктивність автомобілів визначається кількістю пасажирів або масою вантажу, що перевозиться, та його середньою швидкістю. У зв'язку з вищесказаним, продуктивність залежить від наступних чинників: прохідності, потужності двигуна, легкості управління, надійності автомобіля, стану дорожнього покриття тощо.

Можливість використання різних видів пального ще одна вимога яка ставиться до автомобілів, що використовуються у сільськогосподарському виробництві. Використання біологічного та газоподібного пального забезпечує більш економічне виконання технологічних процесів.

Відповідно до пристосованості до дорожніх умов автомобілі діляться на два види: нормальної прохідності (призначені для використання на дорогах 3 твердим покриттям та сухих грунтових дорогах) і підвищеної прохідності (використовують на поганих дорогах та бездоріжжі).

Відповідно до вантажопідйомності рухомий склад автомобільного парку поділяють на: дуже малої вантажопідйомності (до 1 т), малої $(1-3$ т), середньої $(3-5$ т), великої $(5-8$ т) та дуже великої (понад 8 т).

Стислі агротехнічні строки жнив обумовлюють потребу у вдосконаленні автомобільного парку сільськогосподарських виробників. Оптимізація структури транспортного парку забезпечить зниження простоїв збиральних машин і зниження втрат сільськогосподарської продукції за рахунок зменшення часу її збирання. 
Вибір оптимального якісного рухомого складу автомобільного парку нерозривно пов'язано 3 встановленням оптимального часу служби автомобіля та оцінки його надійності. Забезпечення надійності автомобіля $є$ комплексною проблемою, яка починається ще з моменту його проектування, виробництва, експлуатації та правильного сервісного обслуговування аж до завершення його використання.

При використанні у виробничих процесах автомобільного транспорту з низькою надійністю виникає велика кількість простоїв та втрат на обслуговування і ремонт, у зв'язку з чим відбувається зниження продуктивності та зростання собівартості кінцевого продукту, а іноді навіть втрата врожаю.

Разом 3 тим, якщо навіть в процесі проектування та виробництва було забезпечено усі необхідні чинники надійності автомобілів для сільськогосподарського виробництва, то реалізація даного потенціалу високої надійності залежить від подальших умов експлуатації рухомого складу i, в першу чергу, від системності його обслуговування, проведення ремонтних робіт, а також якості їх виконання.

3 метою як найбільш повного використання потенційної надійності потрібне правильне управління процесами експлуатації автомобільної техніки за допомогою розробки та впровадження раціональної, науково-обгрунтованої системи проведення їх ремонту та технічного обслуговування. Повне використання надійності автомобілів, яка закладена на стадіях проектування та виробництва забезпечить підвищення їх продуктивності, що, в свою чергу, дозволить покращити всі економічні показники їх роботи не залучаючи додаткові капітальні вкладення та значне зростання оборотних коштів.

\section{ОБГОВОРЕННЯ РЕЗУЛЬТАТІВ ДОСЛІДЖЕНЬ}

Вище перелічене дозволяє говорити про те, що надійність рухомого складу автомобільного парку сільськогосподарських підприємств $є$ однією із основних економічних категорій і пов'язує їі 3 комплексною системою ремонту й обслуговування та оптимальними строками служби автомобілів. Вибір і дотримання «розумних» строків служби автомобіля $-\epsilon$ одним 3 основних чинників підвищення ефективності сільськогосподарського виробництва як в конкретному господарстві, так і у сільськогосподарському виробництві загалом.

Найбільший вплив, з усіх показників надійності, на кінцевий результат роботи транспортних засобів, на нашу думку, має безвідмовність і довговічність. Це пояснюється тим, що дані показники визначають подальші витрати на поточні та капітальні ремонти, а також на усунення відмов, що виникають під час експлуатації рухомого складу автомобільного парку сільськогосподарських підприємств, а отже й на економічну ефективність їх використання. На інші показники надійності, такі як збереженість і ремонтопридатність, під час експлуатації впливати значно важче, оскільки вони закладаються, в основному, ще на стадії проектування транспортних засобів.

\section{ВИСНОВКИ}

Високі показники сезонності, стислі терміни збирання, поганий стан автомобільного парку створюють значні проблеми для сільськогосподарських виробників у процесі транспортування продукції від комбайна до місця зберігання чи переробки. 3 метою забезпечення ефективного використання транспортних засобів в процесі перевезення сільськогосподарської продукції необхідно проводити наукову оптимізацію транспортних потоків, встановлення можливого скорочення витрат у системі «поле-процес транспортування-склад».

Отже, до основних шляхів поліпшення використання рухомого складу автомобільного парку сільськогосподарських виробників належать: підвищення коефіцієнту змінності роботи, повноти використання у виробничих процесах, ліквідацію простоїв, скорочення часу перебування у ремонті й оглядах, стимулювання кращого використання автомобільного транспорту.

Використовуючи сучасні способи розрахунку об'єму перевезень і покращення експлуатаційних характеристик автомобільного парку можна забезпечити розв'язання такої задачі, як схоронності сільськогосподарської продукції.

\section{ПЕРЕЛІК ДЖЕРЕЛ ПОСИЛАНЬ}

1. Маяк М.М. Особливості розвитку ринку вантажних і пасажирських перевезень/ М. М. Маяк, П. Б. Прогній, А. Й. Матвіїшин, П. В. Попович, О. С. Шевчук, В. М. Островерхов, А. С. Коцур, О. В. Романишин // Сучасні технології в машинобудуванні та транспорті. - ЛНТУ. Луцьк, 2020. № 2(15). - C. 64-72.

2. Maurizio Bielli et al. Trends in Models and Algorithms for Fleet Management / Maurizio Bielli Alessandro Bielli, Riccardo Rossi // Procedia Social and Behavioral Sciences 20, 2011. - p. 4-18. 
3. Redmer A. Strategic vehicle fleet management - the composition problem / A. Redmer // LogForum 11 (1), 2015. - p. 119-126.

4. Anylogic Simulation Software (2019). - Режим доступу: https://www.anylogic.com

5. Наумов В.С. Формування раціональної структури автопарку в умовах випадкових характеристик потоку замовлень на перевезення вантажів: автореф. дис. канд. техн. наук: 05.22.01 / В. С. Наумов // Харківський національний автомобільно-дорожній університет. - X, 2006. - 22 с.

6. Прогній П. Б. Пошукове конструювання колісних транспортних засобів / П. Б. Прогній, Ю. В. Дзядикевич, О. П. Захарчук, М. М. Маяк, П. В. Попович та ін. // Сучасні технології в машинобудуванні та транспорті. - ЛНТУ. Луцьк, 2021. - № 1 (16). - С. 88-99.

7. Кравченко О.П. Надійність систем активної безпеки автомобілів-тягачів / О.П. Кравченко, С.Л. Зубачик, Р.Г. Мухін // Вісник східноукраїнського національного університету імені Володимира Даля. - Сєвєродонецьк, 2017. - № 4 (234). - С. 115-118.

8. Кубіч В. І., Слинько Г. І. Складові частини об'єктів транспортного машинобудування. Навчальний посібник: 2-ге вид., перероб. і доп. / В. І. Кубіч, Г. І. Слинько // НУ «Запорізька політехніка», Запоріжжя, 2021. - 363 с.

\section{REFERENCES}

1. Maiak M.M. Osoblyvosti rozvytku rynku vantazhnykh i pasazhyrskykh perevezen/ M. M. Maiak, P. B. Prohnii, A. Y. Matviishyn, P. V. Popovych, O. S. Shevchuk, V. M. Ostroverkhov, A. S. Kotsur, O. V. Romanyshyn // Suchasni tekhnolohii v mashynobuduvanni ta transporti. - LNTU. Lutsk, 2020. - № 2(15). S. 64-72.

2. Maurizio Bielli et al. Trends in Models and Algorithms for Fleet Management / Maurizio Bielli Alessandro Bielli, Riccardo Rossi // Procedia Social and Behavioral Sciences 20, 2011. - p. 4-18.

3. Redmer A. Strategic vehicle fleet management - the composition problem / A. Redmer // LogForum 11 (1), 2015. - p. 119-126.

4. Anylogic Simulation Software (2019). - Режим доступу: https://www.anylogic.com

5. Naumov V.S. Formuvannia ratsionalnoi struktury avtoparku $\mathrm{v}$ umovakh vypadkovykh kharakterystyk potoku zamovlen na perevezennia vantazhiv: avtoref. dys. kand. tekhn. nauk: 05.22.01 / V. S. Naumov // Kharkivskyi natsionalnyi avtomobilno-dorozhnii universytet. - Kh., 2006. $-22 \mathrm{~s}$.

6. Prohnii P. B. Poshukove konstruiuvannia kolisnykh transportnykh zasobiv / P. B. Prohnii, Yu. V. Dziadykevych, O. P. Zakharchuk, M. M. Maiak, P. V. Popovych ta in. // Suchasni tekhnolohii v mashynobuduvanni ta transporti. - LNTU. Lutsk, 2021. - № 1 (16). - S. 88-99.

7. Kravchenko O.P. Nadiinist system aktyvnoi bezpeky avtomobiliv-tiahachiv / O.P. Kravchenko, S.L. Zubachyk, R.H. Mukhin // Visnyk skhidnoukrainskoho natsionalnoho universytetu imeni Volodymyra Dalia. - Sievierodonetsk, 2017. - № 4 (234). - S. 115-118.

8. Kubich V. I., Slynko H. I. Skladovi chastyny obiektiv transportnoho mashynobuduvannia. Navchalnyi posibnyk : 2-he vyd., pererob. i dop. / V. I. Kubich, H. I. Slynko // NU «Zaporizka politekhnika», Zaporizhzhia, 2021. - $363 \mathrm{~s}$.

\section{Rozum R., Buriak M., Zakharchuk $O$. Use of road transport in agricultural production}

The development of agricultural production directly depends on the state of the technological base of agricultural producers. Road transport has been significantly used in the transportation of agricultural materials from the place of harvest to the places of its storage and processing. The task of establishing the optimal size of the fleet is relevant for both freight and passenger traffic. The solution to this problem should ensure the determination of the composition and quantity of the fleet, which would ensure the implementation of the necessary technological processes, on the one hand, and the maximum elimination of downtime, which leads to additional costs, on the other. Cars used in agricultural production must meet the relevant operational requirements. Such requirements include ensuring the implementation of the whole complex of agricultural work with proper productivity and maximum efficiency. The requirements for environmental friendliness (emissions of harmful components and soil compaction) and comfort and safety are also important. The choice of the optimal quality rolling stock of the car fleet is inextricably linked with the establishment of the optimal service life of the car and the assessment of its reliability. Ensuring the reliability of the car is a complex problem that begins from the moment of its design, production, operation and proper maintenance until the end of its use. The main ways to improve the use of rolling stock of agricultural vehicles include: increasing the coefficient of variability, completeness of use in production 
processes, elimination of downtime, reducing downtime in repairs and inspections, stimulating better use of road transport.

Key words: car, motor transport, agricultural production, agricultural machines, rolling stock.

РОЗУМ Руслан Іванович, кандидат технічних наук, доцент, доцент кафедри транспорту i логістики, Західноукраїнський національний університет, Тернопіль, Україна, е-таil: rozoom_ruslan@ukr.net. https://orcid.org/0000-0001-7812-8248

БУРЯК Микола Васильович, кандидат технічних наук, доцент, доцент кафедри транспорту і логістики, Західноукраїнський національний університет, Тернопіль, Україна, е-таil: rozoom_ruslan@ukr.net.https://orcid.org/0000-0001-5332-1498

ЗАХАРЧУК Олена Павлівна, кандидат технічних наук, доцент, доцент кафедри транспорту і логістики, Західноукраїнський національний університет, Тернопіль, Україна, е-таil: olenaskyba8500@gmail.com. https://orcid.org/0000-0001-9452-9850

Ruslan ROZUM, Doctor of Philosophy, Associate Professor of Transport and Logistics department, West Ukrainian National University, Ternopil, Ukraine, e-mail: olenaskyba8500@gmail.com.

https://orcid.org/0000-0001-7812-8248

Mykola BURIAK, Doctor of Philosophy, Associate Professor of Transport and Logistics department, West Ukrainian National University, Ternopil, Ukraine, e-mail: olenaskyba8500@gmail.com. https://orcid.org/0000-0001- 5332-1498

Olena ZAKHARCHUK, Doctor of Philosophy, Associate Professor of Transport and Logistics department, West Ukrainian National University, Ternopil, Ukraine, e-mail: olenaskyba8500@gmail.com. https://orcid.org/0000-0001-9452-9850

DOI 10.36910/automash.v2i17.644 